\title{
The Relationship between Green Supply Chain Management and Profitability
}

\author{
Dina Allam, Elsayed Elseify, Amr Youssef, Nevien Khourshed \\ The Arab Academy for Science and Technology \& Maritime Transport, Alexandria, Egypt \\ Email: d.allam24@yahoo.com, hwssiefy@gmail.com, amraziz@aast.edu,nevienkhourshed@aast.edu
}

How to cite this paper: Allam, D., Elseify, E., Youssef, A. and Khourshed, N. (2021) The Relationship between Green Supply Chain Management and Profitability. Open Access Library Journal, 8: e5892.

https://doi.org/10.4236/oalib.1105892

Received: October 30, 2019

Accepted: February 19, 2021

Published: February 22, 2021

Copyright (๑) 2021 by author(s) and Open Access Library Inc.

This work is licensed under the Creative Commons Attribution International License (CC BY 4.0).

http://creativecommons.org/licenses/by/4.0/

(c) (i) Open Access

\begin{abstract}
In today's business environment, companies are facing increased pressure from different sources, such as consumers and communities, stricter governmental regulations and scarcity of resources; to enhance their sustainable behavior. This escalating global awareness of the impact of manufacturing and operational processes on the environment has translated into increased managerial action to balance incorporates economic, financial and environmental performance. Green Supply Chain Management (GSCM) has emerged as an important organizational philosophy to achieve targeted economic and market objectives while reducing environmental risk, reducing cost, optimizing resources and enhancing operations throughout the supply chain. Green supply chain management practices, activities, and their impact on different aspects of corporate performance have been gaining increased attention from academia, industry and customers. The current research aims to investigate the effect of GSCM practices; Greenhouse Emissions, Recycling, Waste, and Renewable Energy on firms' profitability. Results showed that waste had a significant negative impact on the profitability measured by return on equity which implied that companies should strive to reduce their waste to be able to increase their profitability.
\end{abstract}

\section{Subject Areas}

Supply Chain Management, Finance, Accounting

\section{Keywords}

Green Supply Chain Management, Green Supply Chain Practices, Firm Profitability

\section{Introduction}

It has been acknowledged that the supply chain is an interconnected system that incorporates the entire sequence of activities and grouping of exercises from dis- 
tribution of services or products to its end utilization, consumption and disposal, including various actors, working on various scales and areas and incorporating the material or product's production, assembly, and delivery. It is conceivable to monitor around streams of materials, share systems, techniques, knowledge, and procedures with supply chain partners, team up coordinate to control the natural and environmental hazard and produce environmentally friendly products [1].

Lately, customer interest in obtaining and purchasing environmentally friendly products has expanded. This has constrained businesses to extend the activities of their supply chains, the encapsulated carbon content of their product, and the general supportability of their activities or sustainability of their operations. Thus, Green Supply Chain Management (GSCM) has been engaged and emerged as an important organizational philosophy to achieve targeted profit and market objectives while reducing environmental risk, reducing cost, optimizing resources, and enhancing operations throughout the supply chain [2].

\section{Literature Review}

The deterioration of the environment led to therelease of the concept and the principle of green supply chain management which is considered as the recent environmental strategy. To implement this strategy, organizations should make an integrated collaboration between internal practices or procedures, and external practices including material suppliers, whole sellers to deliver a high-quality value to the end consumers. On the other hand, during the previous decade, society everywhere has stirred to the issue of environmental change.

Accordingly, Green supply chain management practices and their impact on various aspects of corporate performance have been gaining increased attention from academia, industry, and customers. Hence, the focus of this research is to investigate the impact of the green supply chain practices on firms' profitability. This research aims to fill the research gap identified as a lack of empirical evidence on the investigated point.

Literature had been reviewed that the green supply chain management practices effect on different parts of corporate performance has gained an expanded consideration from both academics, and practitioners. Hence, the exploration of this research has been made to fill the research gap distinguished to provide empirical evidence on the researched point and give proposals and recommendations to scholastics, experts, academics, and practitioners [2].

The aim and the objective of the research appear in developing a framework of green supply chain management, which would be able to help organizations to improve the practices of green supply chain management. Based on this aim, research objectives are set as exploring the impact of GSCM practices (Greenhouse Emissions, Recycling, Waste, and Renewable Energy) on profitability (ROE).

\subsection{Green Supply Chain Management (GSCM)}

It was claimed that the GSCM is also known as the environmental supply chain 
management (ESCM) or sustainable supply chain management (SSCM). All of these concepts are defined as the integration of green purchasing, green manufacturing/materials management, green distribution/marketing, and reverse logistics into the organizational operations [3].

Another definition of the green supply chain management is considered as the one introduced by [4] who defined environmental supply chain management as the inclusion and the integration of management in the flow and the stream of material and information through the supply chain to make the customers feel satisfied from their green products and services. These supply chains contend to look for internal health using the ability of the auto-correction based on external environment information.

In addition, it was claimed that sustainable supply chain management appeared as the main approach for organizations to follow environmentally sustainable manner, those organizations are increasing and start to merge the environmental practices in their plans and strategies. It was also claimed that the definitions and concepts that are related to the supply chain environmental and ecological management are usually clear and understood by organizations and industries as environmental performance [5].

Moreover, the supply chain management traditional definition is the process of converting the raw material to final products and delivering those products to consumers. However, according to the recent environmental changes, the concept and the idea of supply chain management has been enhanced and improved so that the green supply chain consists of many factors that lead to improving the environmental and ecological supply chain and provide a technique and procedure to achieve it. Thus, the green supply chain is the new concept of the traditional supply chain as many activities are maintained to reduce the environmental impacts, those activities include green purchasing, green design, decreasing of damaged material, and product recycling.

Furthermore, the green supply chain was also defined as the set of integrating environmental thinking into the traditional supply chain management to balance and stabilize the environmental performance and financial performance of the organizations [7]. GSCM gained more popularity and attention as more countries are considering the environmental and economic effects of the organizational operations as well as the rise in the public awareness of environmental safety [6].

Meanwhile, it is also necessary for organizations to green their audit management system to ensure that suppliers and vendors meet the quality standards of the products and raw materials. This will help suppliers to achieve a well understanding of the industry's environmental strategy. In addition, the implementation of innovating green practices is containing the environmental management system (EMS) implementation, usage, green procurement (acquirement) strategies, green product development, and design (configuration) practices adoption, use, and utilization of environment-friendly products and process 
optimization (procedure streamlining), use of environmentally friendly and naturally benevolent packing and labeling of the firms' products [8].

\subsection{Greenhouse Emissions and Firm Profitability}

Recently, environmental change and environmental strategy are higher on the brains of shoppers and consumers around the globe than at any other time. As scholars, top administration, and management have identified environmental change and carbon management as a business reality now [9].

Inside the setting and the context of a carbon and greenhouse emissions constrained business future, there is extraordinary vulnerability and uncertainty over how a move to a low-carbon business market will play out and how to reduce the greenhouse emissions [9]. A lot of scholastics and supervisors are giving a big concern about the environmental strategy especially carbon management. Researchers tried to find another approach to incorporate carbon emissions in the production network and supply chain management. Since environmental change and carbon emissions present difficulties to numerous businesses and industries, expanding their comprehension of how to coordinate carbon emissions in supply chain management, inventory, and production process [9].

Besides, greenhouse emission reduction has been introduced as a tool that helped in reducing the environmental impact of the supply chain process, especially in the manufacturing phase to produce cleaner goods and services. The main successful keys of greenhouse emission reduction are to make an integrated and helpful system of management commitments, awareness of employees, and training. Management commitments refer to managers' responsibility for planning, implementing, and controlling corrective processes to enhance the eco-system. Also, to create innovations, technologies, programs, and activities to encourage the employees to work harder and reduce wasted materials, produce the integration of products in a cleaner way, reduce product pollution, and enhance organizational profitability. In addition, it is one of the main procedures that improve and strengthen the profitability and efficiency of the firms [2]. Consequently, this research proposes the following main hypothesis:

$H_{1}$ : There is a significant relationship between Greenhouse Emissions and a firm's profitability measured by ROE.

\subsection{Recycling and Firm Profitability}

A lot of focus and concern has been delivered about design for disassembly and for recycling the products by most large corporations which apply the GSCM. Some scholars have concluded that greening the supply process and greening the stock procedures represent adaptations and adjustments to supplier management activities. Other broad exercises include collaboration and incorporation of a coordinated effort with suppliers to eliminate packaging, reusing, and recycling initiatives. Using and utilizing exploratory analysis and examination of im- 
plementation patterns, executing examples, and inductively derived analysis. Also, it was determined that recycling is one of the main green supply initiatives, in addition to being viewed as one of the most and main procedures that are applied in enterprises in implementing the GSCM practices [10].

[11] investigated among all the recorded recycling procedures, structure for recycling, and plan for disassembly have all the earmarks of being the least common studied. They mentioned that there are two last techniques introduced as the principal purpose of recycling procedures. The first one is planning and designing for disassembly focus on a diminishing the cost of destroying a product, which can thusly prompt improved recycling and reusing of the product itself, or parts thereof. As an outcome, the waste streams related to the item itself are diminished, weakened and the effects and impacts related to the process of production of a new product or parts are reduced.

The second one is planning and designing for recycling focuses on utilizing more recycled materials in the manufacturing process, assembling procedures, and making the products simpler to reuse and recycle. Consequently, the impact of the product is rapidly diminished by the collection and recycling procedures of certain materials, where they have a less environmental and ecological impact than producing an equivalent amount of similar material from primary assets and resources. Recycling plan is regularly an exceptionally effective strategy, giving a considerable lessening in environmental and ecological effects and simultaneously permitting savings in the utilization and consumption of natural resources and assets which increases the organizational profitability [11]. Consequently, this research proposes the following main hypothesis:

$\mathrm{H}_{2}$ : There is a significant relationship between Recycling and a firm's profitability measured by ROE.

\subsection{Waste and Firm Profitability}

Most of the large profitable companies aim to grow more effectively and establish new ways and strategies to improve their green brand in order to create a value proposition in customers' minds and to make a competitive advantage that differentiates them from other competitors. Green brand refers to companies that provide eco-friendly products and services to serve in environmental protection and its target customers who focus on healthy products and services and are interested in eco-friendly products and reducing the waste of their production processes. Therefore, the supply chain of those firms comprises of those exercises related to assembling from raw material procurement to final product delivery to focus on eco-friendly products and how to reduce the waste of their manufacturing facilities [12].

As of the late changed environmental prerequisites and agreements that influence production activities and transportation structures, developing consideration is given to the advancement and development of environmental administrative procedures and strategies for supply chains. Green supply chains aim at 
linking the wastes to the industrial structure and systems to save energy and forestall the dissipation of unsafe and harmful materials into the near environment. Therefore, each link or channel in the supply chain could be a reason to generate waste, or any hazards to the environment would be eliminated or reduced as one of the practices of GSCM [13].

Also, it has been noticed that most managers and executives who apply the GSCM practices in their facilities are focusing on reducing emissions and wastes especially the mercury waste and emissions, and applying improvement to their environmental performance by implementing recycling procedures and programs such as recycling and materials recovery. Therefor another hypothesis could be formulated as follows:

$H_{3}$ : There is a significant relationship between Waste and a firm's profitability measured by ROE.

\subsection{Renewable Energy and Firm Profitability}

By reviewing previous studies, it has been found that the relationship between green logistics and energy demand had great importance under the GSCM process, while sustainability in the point of view of green logistics indicators needs sustainable and renewable sources of energy to diminish the destructive impact of worldwide logistics activities and practices on nature and the environment. It has been settled that GSCM practices are a set of procedures to enhance environmental sustainability. Also, it has been investigated and proved that environmental sustainability could be improved by reducing carbon emissions and one of the main methods used to reduce carbon emissions is introducing the concept of consuming renewable energy as a percentage of total energy consumption [14].

Green development could be achieved by utilizing cleaner energy or green energy as one of the promising solutions which could be done by government regulations to support using cleaner technology in industrial activities and the production process. Other empirical research directed with regards to China has been clarified that Chinese firms and organizations keep attempting to improve their ecological and environmental picture with cleaner production, sustainable power source, and renewable energy. In the other word, the GSCM practice's concern with the energy resources which are vital and indispensable to power and control the industrial processes and procedures in manufacturing, assembling, and logistics, while their use and utilization are also a major and significant contributor to carbon emissions and waste [1].

Therefore, the integrative nature of GSCM gives and provides conditions for improvement and progress in utilization and accessibility of energy and can facilitate the transition and encourage the change in which fossil fuels and petroleum derivatives are replaced with a system and arrangement of supply and conversion of sustainable renewable energy. It has been highlighted by the GSCM and the national scale economic indicators that energy efficiency im- 
proves the total economic growth under the current amount of labour and capital. Also, it has been noticed that the firms' profitability and their reputation in the market have been increases significantly after those firms have used renewable energy sources and applied green practices in their production process [14], [1]. Consequently, this research proposes the following main hypothesis:

$H_{4}$ : There is a significant relationship between Renewable Energy and a firm's profitability measured by ROE.

\section{Research Methodology}

The business research is demonstrated and shaped like one of the social sciences researches at large by the intellectual traditions. Thus, it is elaborated and followed by the context of the social science disciplines, which inform the study of business and its specific fields. It had been defined as an applied field that focuses on the nature of organizations and also focuses on solving problems that are facing the managers and related to managerial practice. It is obligatory to be clear in defining the theory, which is as an explanation of observed regularities or to explain the degree of alienation between two or more variables. In the following sections, the researcher will try to identify the methodology that is used to examine and test the hypotheses and explain the results obtained through testing the research sample in applying Green Supply Chain [15].

This research follows the positivism philosophy to understand the structures that generate events of the green supply chain by identifying its perspectives and different dimensions. In addition, the researcher follows this philosophy to gain the advantage of fulfilling the gaps between the finding and build the research hypotheses objectively. Using this philosophy allows the researcher to test the hypotheses according to theories of green supply chain and provide further findings of the phenomenon conducted about the relationship between green supply chain and profitability indicators.

The research process is devoted to the explanation of relationships between variables which helps the researcher to find and choose the best justification of the findings of this research. The researcher follows a deductive approach as this research clearly defines the used dimensions in different theories as well as the extent to which such dimensions are applied in practice. Thus, the researcher will examine the effect of green supply chain practices on firm profitability [15].

Since the research approach adopted in this study is the deductive approach, then, the quantitative research design will be the proper choice for examining relationships between variables. According to the discussion presented in this section, the next section presents different types of data, the ways to collect data, and the types and methods that have been used by the research method. The discussion raised regarding the data collection is described in the following section in detail to be able to specify different tools used for this research [16].

\subsection{Data Collection and Sample Selection}

This research has been focused on secondary data to measure the profitability of 
twelve companies from the year 2014 to the year 2019. The study is based on secondary data observation as a tool of data collection which is a method for quantitative data. The researcher collected historical secondary data from corporate annual and sustainability reports.

Variables and Measurement: The variables used in this study can be categorized into two main types which are the dependent and independent variables.

Dependent Variable is the profitability. The performance will be measured by the Return on Equity (ROE). ROE is treated as an important measure of a company's earnings performance. The ROE tells common shareholders how effectively their money is being employed. With it, one can determine whether a firm is a profit-creator or a profit-burner and management's profit-earnings efficiency. The higher a company's return on equity, better management is at employing investors' capital to generate profits.

Independent Variables: These are factors identified in prior research as GSCM practices. There are four independent variables that will be measured. These are The Greenhouse Emissions, Recycling, Waste, and Renewable Energy. This research tried to look at the possibility of the relationship between the dependent variable and independent variables. The relationship between the dependent variable and independent variables is explained in Figure 1.

\subsection{Research Variables Conceptualization and Operationalization}

Table 1 presents a summary for the conceptualization of all the variables including the dependent, independent variables of the study.

\section{Findings and Analysis}

This section of the study is devoted to present the results of the analysis performed on the data collected to test the hypotheses developed in the study. Table 2 shows the descriptive statistics of the research variables. It provides the mean, minimum, maximum, and standard deviation of the variables in the study. The data shows that the mean value for Greenhouse Emissions is 5.088. The results

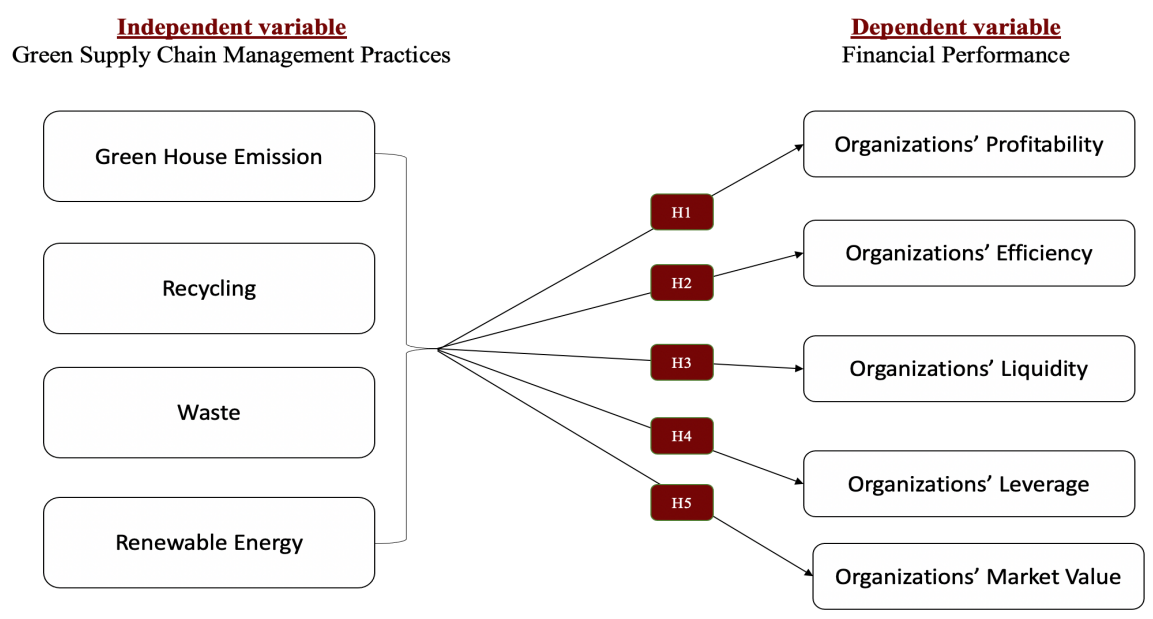

Figure 1. Research model. 
Table 1. Summary of conceptualization of dependent, independent variables.

\begin{tabular}{|c|c|c|c|}
\hline Variables & Dimensions & Definitions & Measurement \\
\hline & & Independent Variable & \\
\hline \multirow{5}{*}{$\begin{array}{l}\text { Green Supply } \\
\text { Chain } \\
\text { Management }\end{array}$} & $\begin{array}{l}\text { Greenhouse } \\
\text { Emissions }\end{array}$ & $\begin{array}{l}\text { They are gases that have } \\
\text { been produced with the } \\
\text { process of production } \\
\text { according to the Kyoto } \\
\text { Protocol [17] }\end{array}$ & $\begin{array}{l}\text { measured using tons of } \mathrm{CO}_{2} \\
{[22]}\end{array}$ \\
\hline & Recycling & $\begin{array}{l}\text { Processing of waste (i.e. } \\
\text { undesirable or futile } \\
\text { materials) back to the } \\
\text { material cycle with the goal } \\
\text { that contamination of the } \\
\text { earth is limited [18] }\end{array}$ & $\begin{array}{l}\text { measured using a percentage of } \\
\text { materials reused out of the } \\
\text { total materials used in the } \\
\text { industry through one whole } \\
\text { year [22] }\end{array}$ \\
\hline & Waste & $\begin{array}{l}\text { Anything that adds adverse } \\
\text { effects to the } \\
\text { an environment without } \\
\text { adding value [19] }\end{array}$ & $\begin{array}{l}\text { Measured using the tons of } \\
\text { resources discarded or unused } \\
\text { resources throughout the year. } \\
{[22]}\end{array}$ \\
\hline & $\begin{array}{l}\text { Renewable } \\
\text { Energy }\end{array}$ & $\begin{array}{l}\text { Energy could be utilized } \\
\text { over and over [20] }\end{array}$ & $\begin{array}{l}\text { Measured using the megawatts } \\
\text { of energy generated from } \\
\text { renewable resources. } \\
{[22]}\end{array}$ \\
\hline & \multicolumn{3}{|c|}{ Dependent Variables } \\
\hline Profitability & ROE & $\begin{array}{l}\text { measures productivity by } \\
\text { uncovering how a lot of } \\
\text { benefits an organization } \\
\text { creates with the cash } \\
\text { investors have contributed } \\
\text { [21] }\end{array}$ & $\begin{array}{l}\text { Measured as a percentage of } \\
\text { net income after tax to total } \\
\text { equity }[21] \\
\text { ROE }=\frac{\text { net income }}{\text { Total Equity }}\end{array}$ \\
\hline
\end{tabular}

show that the mean value of Recycling is 52.295. The mean value for Waste is 190.905 and the mean value for Renewable Energy is 126.991. In addition, the mean return on equity $\mathrm{ROE}$ is 0.113 .

\section{Testing the Research Hypotheses}

The research hypotheses were tested using OLS regression. Accordingly, all the assumptions were tested and verified as the regression model was found to be linear and no hetroscadiscity was found. Moreover, no autocorrelation and multicollinearity exist.

Table 3 shows the summary of the models of the backward stepwise regression. In which the final model has an $\mathrm{R}$ square of $8.5 \%$ which means that $8.5 \%$ of the variation in ROE is affected by the waste with a significance of 0.042 .

Table 4 shows the multiple regression model of the effect of Greenhouse Gas 
Table 2. Descriptive statistics.

\begin{tabular}{lccccc}
\hline & N & Minimum & Maximum & Mean & $\begin{array}{c}\text { Std. } \\
\text { Deviation }\end{array}$ \\
\hline $\begin{array}{l}\text { Greenhouse Emissions } \\
\text { (in Millions) }\end{array}$ & 72 & 0.103 & 19.249 & 5.088 & 5.422 \\
$\begin{array}{l}\text { Recycling } \\
\text { (in thousands) }\end{array}$ & 72 & 1.111 & 157.500 & 52.295 & 47.964 \\
$\begin{array}{l}\text { Waste } \\
\text { (in thousands) }\end{array}$ & 72 & 3.154 & 778.430 & 190.905 & 183.048 \\
$\begin{array}{l}\text { Renewable Energy } \\
\text { (in Millions) }\end{array}$ & 72 & 0.004 & 351.000 & 126.991 & 106.921 \\
\begin{tabular}{l} 
Return on Equity \\
\hline
\end{tabular} & 72 & 0.027 & 0.208 & 0.113 & 0.037 \\
\hline
\end{tabular}

Table 3. Backward stepwise multiple regression model summary.

\begin{tabular}{cccccc}
\hline \multicolumn{7}{c}{ Model Summary } \\
Model & $\mathrm{R}$ & R Square & $\begin{array}{c}\text { Adjusted } \mathrm{R} \\
\text { Square }\end{array}$ & $\begin{array}{c}\text { Std. The error of the } \\
\text { Estimate }\end{array}$ & Sig. \\
\hline 1 & $0.328^{\mathrm{a}}$ & 0.108 & 0.026 & 0.2956350 & $0.275^{\mathrm{b}}$ \\
2 & $0.328^{\mathrm{b}}$ & 0.108 & 0.048 & 0.2923488 & $0.159^{\mathrm{c}}$ \\
3 & $0.321^{\mathrm{c}}$ & 0.103 & 0.064 & 0.2898862 & $0.082^{\mathrm{d}}$ \\
4 & $0.291^{\mathrm{d}}$ & 0.085 & 0.065 & 0.2896616 & $0.042^{\mathrm{e}}$ \\
\hline
\end{tabular}

apredictors: (Constant), Renewable energy (kWh), Greenhouse Emissions (Tons), Recycling (Tons), Waste (Tons); ${ }^{\mathrm{b}}$ Predictors: (Constant), Renewable energy (kWh), Recycling (Tons), Waste (Tons); ${ }^{\mathrm{c}}$ Predictors: (Constant), Recycling (Tons), Waste (Tons); ${ }^{\mathrm{d} P r e d i c t o r s: ~(C o n s t a n t), ~ W a s t e ~(T o n s) ; ~}{ }^{\mathrm{e}}$ Dependent Variable: ROE.

Table 4. Backward stepwise multiple regression model of greenhouse gas emissions on ROE.

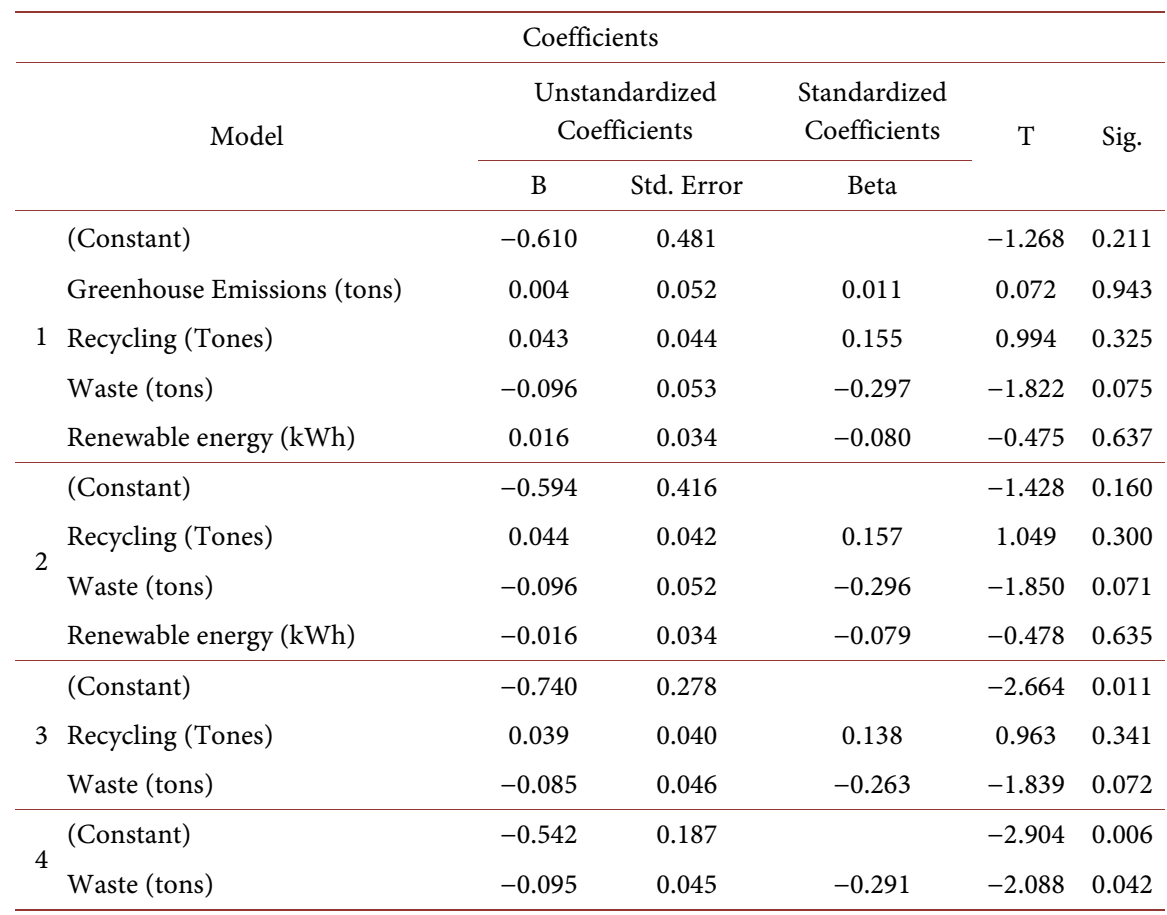

${ }^{\mathrm{a} D e p e n d e n t ~ v a r i a b l e: ~ R O E . ~}$ 
Emissions, recycling, waste, and renewable energy on ROE. The model was found insignificant. Accordingly, the researcher conducted a backward stepwise analysis to reach the optimal significant model. Hence, it was found that the waste was the only variable included in the backward stepwise model with a significance of 0.042 and R-Square of $8.5 \%$ which means that $8.5 \%$ of the variation of the ROE can be explained by waste. This means that firms should be aware that to increase their profitability there is a need to waste in the organization.

Based on the research results, the third hypothesis was accepted which indicates that there is a significant negative relationship between waste and organization profitability, while the other hypotheses were proven insignificant. Table 5 summarizes the results of the hypotheses.

\section{Discussion and Conclusions}

It is essential to study and understand the GSCM factors that involve a firm's profitability and also to examine and test the role of GSCM practices in enhancing and upgrading the impact of such factors on a firm's performance. The optimum goal of this research is to develop and understand a framework for GSCM factors that affect a firm's profitability as well as identifying the role of GSCM variables in enhancing and improving the impact of such variables and factors on profitability.

This research was done to explore the role of GSCM practices on a firm's profitability. The impact of Greenhouse Emissions, Recycling, Waste, and Renewable Energy on profitability was examined by applying this quantitative approach proposed in this research. This was handled by examining secondary data collected to calculate the profitability and the green supply chain practices. However, the results and findings of this research were shown in the previous section.

According to the findings of the report, waste has a big effect on the profitability of organizations, which is confirmed by many previous studies. In the green paradigm, for instance, there are many areas where waste occurs, and resources remain to mitigate it, which will ultimately affect organizations' environmental and economic efficiency. Profits are thus achieved for all layers of the

Table 5. Summary of hypotheses results.

\begin{tabular}{clc}
\hline Hypotheses & \multicolumn{1}{c}{ Description } & Results \\
\hline $\mathrm{H}_{1}$ & $\begin{array}{l}\text { There is a significant relation between GSCM Practice } \\
\text { (Greenhouse Emissions) and Profitability, measured by ROE }\end{array}$ & $\begin{array}{c}\text { Not } \\
\text { Supported }\end{array}$ \\
$\mathrm{H}_{2}$ & $\begin{array}{l}\text { There is a significant relation between GSCM Practices } \\
\text { (Recycling) and Profitability, measured by ROE }\end{array}$ & $\begin{array}{c}\text { Not } \\
\text { Supported }\end{array}$ \\
$\mathrm{H}_{3}$ & $\begin{array}{l}\text { There is a significant relation between GSCM Practices (Waste) } \\
\text { and Profitability, measured by ROE }\end{array}$ & $\begin{array}{c}\text { Supported } \\
\mathrm{H}_{4}\end{array}$ \\
& $\begin{array}{l}\text { There is a significant relation between GSCM Practices } \\
\text { (Renewable Energy) and Profitability, measured by ROE }\end{array}$ & $\begin{array}{c}\text { Not } \\
\text { Supported }\end{array}$ \\
\hline
\end{tabular}


supply chain, as companies would work together to improve the production and production efficiency of their goods, contributing to overall waste reduction [12]. In addition, through the waste that occurs during manufacturing, transport, distribution and disposal, the supply chain adversely impacts the environment, and here the aim of green supply chain management appears to be to mitigate and avoid environmental harm. Therefore, the effort and encouragement of suppliers to comply with the required environmental standards are to achieve supply chain goals. This relationship represents the strong correlation between green buying and better organizational profitability.

In the researcher's view, the findings have shown that the minimization of waste is perceived to be an effective green strategy activity, since waste is viewed as a non-value-adding practice and treated as an environmental enemy. Where processing and producing are considered as the key causes of environmental disruption to waste generation, habitat disturbance, and natural resource depletion. In addition, the outcome of the research indicates that waste management contributes to improving production and gaining a strategic edge as well as improving financial results through the efficiency of the use of raw materials and resources and decreasing waste and disposal.

The researcher explains the application of these activities; greenhouse emissions, recycling, and renewable energy; while the presence of the insignificance relation between these variables and profitability indicates that organizations are unable to achieve higher profits by implementing these practices. However, such activities may be mandated and valued by stakeholders such as governments and consumers and may have a long-term impact on firm financial performance.

\section{Implications of the Study}

The examination of the research findings provided insight into the nature and magnitude of the relationship between various GSCM practices and firms' financial performance. The research findings allow for several administrative ramifications and managerial implications to improve financial performance indicators by using GSCM practices.

The findings of the study should help managers in strategically planning their green supply chain practices and to link those practices to the organizations' financial performance. The key implication emanating from the research results at the managerial level is the need to establish techniques and instruments that will promote and drive the extension of environmental protection to worldwide supply chain acceptance and implementation. Managers may also use analysis models to reliably forecast the nature of the effect on corporate financial metrics arising from the introduction of diverse practices of green supply chain management. In addition, managers should be more concerned din reducing their organizations' waste to increase profitability.

This research has some recommendations according to what was found in the outcomes. The recommendations are to improve profitability by conserving the 
environment by introducing ecosystem in the firms' operations, it is recommended to enhance the usage of GSCM practices and dimensions to be able to guarantee the expected level of preserving the environment and increasing the efficiency of the operations within or without the organization.

\section{Limitations of the Research}

It has been known that in most empirical studies, there are some limitations to this research that might prevent generalizing the findings. One of the main limitations of this research is the small sample size including twelve companies in addition to the short time frame covering ix years. Moreover, only organizational profitability was examined using one indicator namely ROE.

\section{Suggestions for Further Future Studies}

Since this study covered six years from 2014 to 2019, then, further research can consider a longer time frame as the study was limited by the availability of data in the annual reports and sustainable reports. In addition, a comparison across different industries and between regions around the world can be conducted to examine the difference in GSCM practices implementation.

Another avenue for further research is to include more factors that affect the relationships between GSCM practices and profitability of firms such as corporate sustainable growth, and corporate size to reach a significant relationship between dependent and independent variables.

In addition, future researches may examine the organizational financial performance as a whole including profitability, liquidity, leverage, efficiency, and market value to gain a full understating of how GSCM practices impact the overall financial performance of the corporations.

\section{Conflicts of Interest}

The authors declare no conflicts of interest regarding the publication of this paper.

\section{References}

[1] Fernando, Y., Bee, P.S., Jabbour, C.J.C. and Thomé, A.M.T. (2018) Understanding the Effects of Energy Management Practices on Renewable Energy Supply Chains: Implications for Energy Policy in Emerging Economies. Energy Policy, 118, 418-428. https://doi.org/10.1016/j.enpol.2018.03.043

[2] Acquaye, A., Ibn-Mohammed, T., Genovese, A., Afrifa, G.A., Yamoah, F.A. and Oppon, E. (2018) A Quantitative Model for Environmentally Sustainable Supply Chain Performance Measurement. European Journal of Operational Research, 269, 188-205. https://doi.org/10.1016/j.ejor.2017.10.057

[3] Chien, M.K. and Shih, L.H. (2007) An Empirical Study of the Implementation of Green Supply Chain Management Practices in the Electrical and Electronic Industry and Their Relation to Organizational Performances. International Journal of Environmental Science and Technology, 4, 383-394.

[4] Green Jr., K.W., Zelbst, P.J., Meacham, J. and Bhadauria, V.S. (2012) Green Supply 
Chain Management Practices: Impact on Performance. Supply Chain Management: An International Journal, 17, 290-305. https://doi.org/10.1108/13598541211227126

[5] Hasan, M. (2013) Sustainable Supply Chain Management Practices and Operational Performance. American Journal of Industrial and Business Management, 3, 42. https://doi.org/10.4236/ajibm.2013.31006

[6] Ahmed, W. and Najmi, A. (2018) Developing and Analyzing Framework for Understanding the Effects of GSCM on Green and Economic Performance. Management of Environmental Quality: An International Journal, 29, 740-758. https://doi.org/10.1108/MEQ-11-2017-0140

[7] Shafique, M., Asghar, M. and Rahman, H. (2017) The Impact of Green Supply Chain Management Practices on Performance: Moderating Role of Institutional Pressure with Mediating Effect of Green Innovation. Business, Management and Education, 15, 91-108. https://doi.org/10.3846/bme.2017.354

[8] Luthra, S., Garg, D. and Haleem, A. (2015) Critical Success Factors of Green Supply Chain Management for Achieving Sustainability in Indian Automobile Industry. Production Planning \& Control, 26, 339-362.

[9] Lee, K. (2009) Gender Differences in Hong Kong Adolescent Consumers' Green Purchasing Behavior. Journal of Consumer Marketing, 26, 87-96. https://doi.org/10.1108/07363760910940456

[10] Nakao, Y., Amano, A., Matsumura, K., Genba, K. and Nakano, M. (2007) Relationship between Environmental Performance and Financial Performance an Empirical Analysis of Japanese Corporations. Business Strategy and the Environment, 16, 106-118. https://doi.org/10.1002/bse.476

[11] Cerdan, C., Gazulla, C., Raugei, M., Martinez, E. and Fullana-I-Palmer, P. (2009) Proposal for New Quantitative Eco-Design Indicators: A First Case Study. Journal of Cleaner Production, 17, 1638-1643. https://doi.org/10.1016/j.jclepro.2009.07.010

[12] Ho, J.C., Shalishali, M.K., Tseng, T. and Ang, D.S. (2009) Opportunities in Green Supply Chain Management. The Coastal Business Journal, 8, 18-31.

[13] Choudhary, M. and Seth, N. (2011) Integration of Green Practices in Supply Chain Environment-The Practices of Inbound, Operational, Outbound and Reverse Logistics. International Journal of Engineering Science and Technology, 3, 4985-4993

[14] Khan, S.A.R., Zhang, Y., Anees, M., Golpîra, H., Lahmar, A. and Qianli, D. (2018) Green Supply Chain Management, Economic Growth and Environment: A GMM Based Evidence. Journal of Cleaner Production, 185, 588-599. https://doi.org/10.1016/j.jclepro.2018.02.226

[15] Sekaran, U. and Bougie, R. (2016) Research Methods for Business: A Skill Building Approach. John Wiley \& Sons, Hoboken.

[16] Sreejesh, S., Mohapatra, S. and Anusree, M.R. (2014) Business Research Methods: An Applied Orientation. Springer International Publishing, Cham. https://doi.org/10.1007/978-3-319-00539-3

[17] Llop, M. and Tol, R.S. (2013) Decomposition of Sectoral Greenhouse Gas Emissions: A Subsystem Input-Output Model for the Republic of Ireland. Journal of Environmental Planning and Management, 56, 1316-1331.

https://doi.org/10.1080/09640568.2012.717889

[18] Tanskanen, P. (2013) Management and Recycling of Electronic Waste. Acta Materialia, 61, 1001-1011. https://doi.org/10.1016/j.actamat.2012.11.005

[19] Costa, I., Massard, G. and Agarwal, A. (2010) Waste Management Policies for Industrial Symbiosis Development: Case Studies in European Countries. Journal of 
Cleaner Production, 18, 815-822. https://doi.org/10.1016/j.jclepro.2009.12.019

[20] Panwar, N.L., Kaushik, S.C. and Kothari, S. (2011) Role of Renewable Energy Sources in Environmental Protection: A Review. Renewable and Sustainable Energy Reviews, 15, 1513-1524. https://doi.org/10.1016/j.rser.2010.11.037

[21] Maditinos, D., Chatzoudes, D., Tsairidis, C. and Theriou, G. (2011) The Impact of Intellectual Capital on Firms' Market Value and Financial Performance. Journal of Intellectual Capital, 12, 132-151. https://doi.org/10.1108/14691931111097944

[22] http://wwwen.ipe.org.cn/index.html 